Mavi Atlas, 6(1)/2018: 349-370.

Araştırma Makalesi | Research Article

Makale Geliş | Received: 14.02.2018

Makale Kabul | Accepted: 25.03.2018

DOI: $10.18795 /$ gumusmaviatlas.419094

Zeynep BAŞKAN TAKAOĞLU

\author{
Dr. Öğr. Üyesi \\ Gümüşhane Üniversitesi, Sağlı Bilimleri Fakültesi, İş Sağlığı ve Güvenliği Bölümü, Gümüşhane-Türkiye \\ Gümüşhane University, School of Health, Occupational Health and Safety, Gümüşhane-Turkey \\ ORCID: 0000-0003-1706-7933 \\ zeynepbaskan@hotmail.com
}

\title{
Lise Öğrencilerinin Bilim Tarihi Hakkındaki Bilgi Düzeyleri
}

\begin{abstract}
Öz
Çalışmada lise öğrencilerinin bilim tarihi hakkındaki bilgi düzeylerinin tespit edilmesi amaçlanmıştır. Tarama modelinin kullanıldığ gören 9. Sınıf $(N=30)$ ve 10. Sinıf $(N=57)$ öğrencileri oluşturmuştur. Verilerin toplanmasında dört soruluk açık uçlu bir anket kullanılmıştır. Elde edilen veriler içerik analizi doğrultusunda değerlendirilmiştir. Çalışma sonucunda öğrencilerin ilk uygarlıkların ve bilim insanlarının bilime katkısı, bilimsel bilgilerin zaman içerisindeki gelişimi ve bilimsel hikâyeler konusunda yetersiz ve eksik bilgilerinin olduğu ortaya çıkmıştır. Kazanımlarda bilim tarihine yönelik bilgilerin bulunmasına karşın öğrencilerin yeterli bilgilerinin olmaması bilim tarihine ders kitapları ve öğretmenler tarafından yeterince vurgu yapılamasına bağlanabilir. Bu sonuçlar doğrultusunda farklı disiplinlerle ilişkilendirilen bilim tarihi uygulamalarının öğrencilerin bilim tarihini anlamasına yardımcı olabileceği düşünülmektedir.
\end{abstract}

Anahtar Kelimeler: Bilim Tarihi, Lise Öğrencileri, Bilgi Düzeyi.

\section{Knowledge Level of High School Students Regarding History of Science}

\begin{abstract}
Learning science history contributes to student development in many aspects. It improves scientific thinking and inquiry learning skills and helps students gain a critical perspective. For this reason, it was aimed in this study to determine knowledge level of high school students regarding science history. The screening model was used in the study and the sample consisted of 9th grade $(\mathrm{N}=30)$ and 10th grade $(\mathrm{N}=$ 57) students of an Anatolian high school in the province of Gumushane. A survey consisting of four open-ended questions which was developed by the researcher upon examining 9th grade outcomes and receiving opinions of experts was used for data collection. The data was evaluated using the descriptive analysis method. It was found as a result of the study that the students had inadequate and incomplete knowledge about contributions of early civilizations and scientists to science, development of scientific knowledge throughout time, and scientific stories. The students usually showed that they had superficial and commonplace knowledge. The fact that students had inadequate knowledge even though helping students learn about science history is among the outcomes of the educational program might be associated with insufficient emphasis on science history in textbooks and by teachers. In accordance with these results, it is believed that activities related to science history in different disciplines may help students understand science history.
\end{abstract}

Keywords: History of Science, High School Student, Knowledge Level. 


\section{Giriş}

Bilimsel çalışmalar ve gelişmelere bağlı olarak bilgi her geçen gün ilerlemekte ve gelişmektedir. Bilimsel bilginin ortaya çıkışı, bugün kullanılan sıradan bilgilerin bilinmesi kadar kolay olmamıştır. Bugün sıradan kabul edilen birçok buluş ve bilginin zaman içerisindeki gelişimi oldukça uzun çalışma ve gayretlerin neticesinde günümüzdeki şekline ulaşmıştır. İlk bilimsel çalışmaların kökenleri araştırıldığında bilimsel bilgilerin insanların yaşamlarını sürdürme gereksinimlerinden ortaya çıktı̆̆1 belirlenmiştir (Reid ve Fara 2010: 3). Bu bilgilerin zaman içerisindeki gelişiminde ise insanların doğayı anlama ve açıklama çabaları önemli etkenler sağlamıştır (Laçin Şimşek 2009: 130). Örneğin ilk avcıların avladıkları hayvan türlerini, çevresi ve yaşam şartlarını incelemeleri onların daha kolay avlanmalarına yardımcı olmuştur.

Bilimin tarihsel serüveni neticesinde ona olan bakış açısı, bilim, bilim tanımı, bilim tarihi ve bilimsel bilgi kavramları da zaman içerisinde değişmiştir. Bunun sonucunda bilimin sürekli gelişen ve değişen etkinlikler içermesi, içerdiği konular ve yöntemlerde sınırların net olmaması, çok yönlü ve karmaşık bir sentezi barındırmasından dolayı bilimin net bir tanımının yapılamamasına neden olmuştur (Doğan Bora vd. 2006: 32). Buna bağlı olarak bilim ve bilim tarihi çok disiplinli farklı alanların etkileşimini içeren, bu alanların eş güdümlü çalışması neticesinde yeni bilgiler üreterek bilim dünyasına katkı sağlayan bir alan halini almıştır (İmamoğlu ve Çeken 2011: 72).

Zaman içerisinde bilim alanındaki gelişmelerin hızlanması ile teknoloji günlük yaşantımızı, kültürümüzü ve dünyaya bakış açımızı değiştirmiştir (Kılıç 2010: 1). Bunların fen bilimleri eğitimine yansıması ise bilimsel okuryazar bireylerin yetiştirilmesinin amaçlanması şeklinde olmuştur. Fen bilimlerini anlamanın temelinde bilimsel okuryazar olmak yatmaktadır. Bilim okuryazarlığı içerisinde bilimin doğası, matematiğin doğası, teknolojinin doğası ve tarihsel bakış boyutları vardır (AAAS 1993). Buradan da anlaşılacağı gibi bilimsel okuryazar olmanın iki önemli alt boyutunda bilimin doğası ve tarihsel gelişimi bulunmaktadır. Her iki alanın içerisinde 
de bilim insanlarının bilimsel bilgiye ulaşma yolları, bilimsel bilginin özellikleri ve bilimsel bilginin gelişim süreci yer almaktadır (Kapucu ve Çıllgın 2016: 330).

Bilimin doğası da kendi içerisinde incelendiğinde dört önemli ayağından birini bilim tarihi oluşturmaktadır (Kaya 2007: 4). Bilimin doğasının anlaşılması ile bilimsel bilginin ortaya çıkışı, gelişimi ve önemi daha kolay bir şekilde açıklanabilir (Yıldız 2003: 8). Bu alan yardımıyla bilim insanlarının bilimsel bilgiye nasıl ulaştıkları, bilimsel bilginin özellikleri ve zaman içerisindeki gelişimi de incelenmektedir. Bu nedenle bilimin doğası tabiatı gereği bilim tarihi ile iç içedir ve bilimin doğasında yürütülen çalışmaların önemli bir parçasını bilim tarihi barındırır.

Bilimin doğasının bilimsel okuryazarlık için en önemli etkenlerden birisi olduğu unutulmamalıdır. $\mathrm{Bu}$ bağlamda düşünüldüğünde bilim tarihinin bilimsel okuryazar olmaya önemli katkılar sağlayabileceği açıktır. Bilim tarihine yönelik yürütülen derslerle öğrenciler önceki bilim insanlarının bilimsel çalışmalarda izledikleri yollar, bir araştırmanın planlama, yürütme, yorumlama, sonuçlandırma ve sorgulama becerilerinin gelişmesi ve buna bağlı olarak araştırma ve sorgulamaya dayalı öğretimi gerçekleşecektir (Laçin Şimşek 2009: 130). Ayrıca bilimsel bilginin ortaya çıkışı ve bilimin doğasına yönelik yürütülen derslerin öğrencilerin bilimin felsefi, psikolojik, sosyolojik ve tarihsel gelişimine önemli katkıları olmaktadır (Kaya 2007: 4). Bu sayede öğrenciler bilim ile ilgili daha kapsamlı bir bakış açısıyla olaylara bakma fırsatı bulacaklardır (Tural 2012: 65). Bunun yanında sahip olduğu düşüncenin tarihsel doğasını gören öğrenci kendi kavramsallaştırdığı bilgileri modern bilimsel bilgilerle ilişkilendirerek karşılaştırıp bilim dünyasındaki önemli şahsiyetlerin benzer düşüncelerini fark ederek fene karşı motivasyonu artacaktır (Laçin Şimşek 2009: 130).

Bilim tarihinin bireylerin evrensel bilimi anlama, bilgi birikimi oluşturma, bilgi birikiminin oluşumu ve gelişimini nedenleriyle anlama, eleştirel düşünme becerisine sahip ve sorgulayıcı bireylerin yetişmesine önemli katkıları vardır (Laçin Şimşek ve Şimşek 2010: 193). Ayrıca bilim tarihi destekli derslerle bilimin doğasının, bilim tarihinin ve temel kavramların daha başarılı öğrenildiği bilinmektedir (Ayvacı 2007: 119). Bilim tarihi bilimin doğuş ve gelişme öyküsü olarak ifade edilmektedir (Kılıç 
2010: 3). Buradan da anlaşılacağı gibi olaylar sadece oluş şekliyle dikkate alınmaz, aynı zamanda bu süreçte yaşanılan şartlar, bilim insanlarının yaşadıkları zorluklar, verdikleri uğraşlar, kullandıkları yöntemler göz önüne serilerek bilim tarihi tüm yönleriyle ortaya koyulmaya çalışılır (Topdemir ve Unat 2008: 8). Bu dersler yardımıyla öğrenciler bilimsel bilginin yapılandırılışı ve gelişimi, bilimin gelişimi, bu gelişimin topluma yansımaları, daha fazla geliştirilmesinin farkındalığı, bilimsel bir bakış açısıyla günlük yaşam olaylarını sorgulama, bilime ve araştırma yapmaya ilgi gösterme alanlarında gelişeceklerdir (Tural 2012: 65). Bu yönleri dikkate alındığında bilim tarihi öğrenmenin öğrencilerin olaylara ve olgulara bilim insanlarını da dikkate alarak geniş bir perspektiften bakma imkânı sağladığı ortaya çıkmaktadır.

Bilim tarihinin derslerde yer almasıyla bireylerin bilimin tarihsel gelişim serüvenini anlamalarının, zaman içerisindeki açılımını fark etmelerinin, bilime karşı olumlu tutum geliştirmelerinin ve bir bilim insan gibi düşünebilmelerinin yolu açılmaktadır (Laçin Şimşek ve Şimşek 2010: 193). Bu nedenle bilime katkı yapan uygarlıkların ve bireylerin tanınmasında, okul programlarında bu etkenlerin düşünülmesi oldukça önemlidir. İlköğretimden üniversiteye kadar tüm öğretim kademelerinde bilim tarihine yönelik çalışmalar bireylerin kavramsal gelişimlerine ve ilgilerine önemli katkılar sağlayacaktır. Ders kitapları üzerine yürütülen çalışmalar incelendiğinde bilim tarihine yönelik bilgilerin ders kitaplarında yeterince yer almadığı görülmektedir (Kılıç 2010: 72; Kahraman 2013: 71; Kandil İngeç vd. 2016: 183). Ancak 2005 yılından sonra fen programlarında yürütülen yenileme çalışmaları neticesinde eskiye oranla daha fazla bilim tarihine yönelik bilgilerin yer aldığ ders kitapları ortaya koyulmaya başlanmıştır (Laçin Şimşek ve Şimşek 2010: 195). Bu sayede ders kitaplarıyla bilimsel bilginin elde edilme yolları ve bilginin hangi aşamalardan geçerek bu günkü şeklini aldığı bilinecektir.

Fizik dersi açısından bilim tarihine yönelik bilgiler incelendiğinde 2007 ve 2013 yıllarında revize edilen Fizik dersi öğretim programlarında bilim tarihine yönelik bilgilere yer verilmektedir (İngeç vd. 2016). Bilimin doğası üzerine yürütülen çalışmalar neticesinde bilim tarihinin de öğretimi önem kazanmış ve öğretim programlarına bilim 
tarihine yönelik kazanımlar eklenmiştir. 2013 yılında revize edilen fizik dersi öğretim programında bu bilgilerin \%3 ile \% 18 arasında değiştiği belirtilmektedir (İngeç vd. 2016: 180). Bu kazanımların eklenmesi bilim tarihinin anlaşılması açısından oldukça önemlidir. Ancak bu kazanımların uygulayıcılar tarafından da benimsenmesi ve derslerde bu kriterler dikkate alınarak derslerin yürütülmesi de ayrı bir önem içermektedir. Özellikle fizik dersi öğretim programının değişmesi ile birlikte bazı öğretmenlerin eskide kaldıkları ve derslerini hala geleneksel yöntemlerle anlattıkları bilinmektedir (Kaya 2013: 210). Aynı durumun bilim tarihi açısından da irdelenmesi gerekmektedir. Fizik dersi açısından bilim tarihine yönelik çalışmalar incelendiğinde ders kitapları ve programda yer alan kazanımlar dışında (İngeç vd. 2016: 170; İngeç vd. 2016) öğrencilerin bu kazanımları elde etme durumları ve mevcut bilgilerine yönelik çalışmalar bulunmamıştır. Bu nedenle çalışmanın temel problem durumu fizik dersi öğretim programında yer alan kazanımlar doğrultusunda 9. ve 10. Sınıf öğrencilerinin bilim tarihine yönelik bilgilerinin ne düzeyde olduğunu tespit etmektir. Bu doğrultuda alt problemler ise: “1. Öğrenciler ilk uygarlıkların bilim dünyasına yaptı̆̆ı katkıları ne derece bilinmektedir?”; "2. Öğrenciler bilim dünyasına katkı yapan bilim insanları ve katkılarını ne derece bilmektedirler?”; “3. Öğrenciler bilimsel bilginin gelişimini nasıl yorumlamaktadırlar?”; “4. Öğrenciler bilim tarihi ile ilgili yaşanmış hangi olayları bilmektedirler?".

\section{Yöntem}

\section{Araştırma modeli}

Çalışmada betimsel araştırma modeli kullanılmıştır. Betimsel araştırmalarda var olan bir durum ortamda herhangi bir değişim yapılmadan olduğu şekliyle ortaya koyulur. Betimsel araştırmalarda kullanılan modellerden birisi de tarama modelidir. Tarama modeli var olan ya da var olmuş bir durumun nasıl olduğunun ortaya koyulmasına yönelik çalışmalar olarak ifade edilmektedir (Karasar 2007: 77). Bu çalışmalarda mevcut durum tespit edilerek durumun ne olduğu ve neresinde 
bulunulduğuna cevap aranır (Çepni 2007: 35). Tarama modelinde bir durumun ortaya koyulması amaçlandığı için çoğunlukla anket yöntemi kullanılır ve bu doğrultuda veriler analiz edilerek sunulur. Bu çalışma lise öğrencilerinin bilim tarihi konusunda var olan bilgilerini ortaya koymaya yönelik olduğundan tarama modeli niteliğindedir.

\section{Örneklem}

Çalışmanın örneklemini 2016- 2017 eğitim öğretim yılında Gümüşhane ilinde bir Anadolu Lisesinde öğrenim gören 9. sinıf $(\mathrm{N}=30)$ ve 10. sinıf $(\mathrm{N}=57)$ fen kolu öğrencileri oluşturmaktadır. Öğrencilerin yaş aralıkları 15 ve 16 arasında değişmektedir. Çalışmada yer alan öğrencilerin sınıf ve cinsiyete göre dağılımları Tablo 1.'de yer almaktadır.

\begin{tabular}{|c|c|c|c|}
\hline & 9. sinif & 10. sinıf & Toplam \\
\hline Kız & 16 & 27 & 43 \\
\hline Erkek & 14 & 30 & 44 \\
\hline Toplam & 30 & 57 & 87 \\
\hline
\end{tabular}

Tablo1. Araştırmada yer alan öğrencilerin sınıf ve cinsiyete göre dağılımları

Tablo 1.'de de görüldüğü gibi örneklem grubu 87 kişiden oluşmaktadır. Bu örneklemin 30'u 9. sinıfta yer alırken 57'si 10. sinıfta bulunmaktadır. Örneklem grubunun 43'ü kılardan, 44'ü erkeklerden meydana gelmektedir.

\section{Veri toplama aracının geliştirilmesi}

Çalışmada ölçme aracının geliştirilmesi amacıyla öncelikle 2016- 2017 eğitim öğretim yılı 9. Sınıf fizik dersi öğretim programı değerlendirilmiştir. Programda yer alan bilim tarihine yönelik kazanımlar tespit edilmiştir. Belirlenen kazanımlar dikkate alınarak öğrencilerin bilim tarihine yönelik bilgilerini kapsayacak dört soruluk ölçme aracı oluşturulmuştur.

Ölçme aracı hazırlandıktan sonra kazanımlarla ilişkisine ve soruların anlaşılabilirliğine yönelik olarak uzman iki fizik öğretmenine gösterilmiş ve gerekli düzenlemeler yapılmıştır. Ardından hazırlanan ölçme aracının ilk hali asıl uygulamadan 
farklı bir Anadolu Lisesinde öğrenim gören 24 tane 9. Sınıf öğrencisine uygulanmıştır. Öğrenciler tarafından verilen cevaplar incelenerek ölçme aracına son şekli verilmiş ve asıl uygulama sürecine hazır hale getirilmiştir. Asıl ve pilot uygulama sürecinde uygulamalar dersi yürüten fizik öğretmeni tarafından yapılmıştır. Öğrencilerden anketi cevaplarken dürüst davranmaları ve bildikleri tüm bilgileri yazmaları istenmiştir. Öğrencilerle yürütülen uygulamalarda soruların bir ders saati süresi içerisinde tamamlanması istenmiştir. Ölçme aracında yer alan sorular aşağıdaki gibidir.

1. İlk insanlardan günümüze uygarlıkların bilim dünyasına katkılarını yazınız.

2. Bilim insanlarının bilim dünyasına ne gibi katkılar sağladığını örneklerle açıklayınız.

3. Günümüzde kullandığımız buluşların zaman içerisindeki gelişimi hakkında bilgi veriniz.

4. Bazı buluşların ortaya çıkmasında ve/ veya gelişmesinde bildiğiniz hikayeler varsa anlatınız.

\section{Verilerin analizi}

Uygulamadan elde edilen verilerin analizinde içerik analizi kullanılmıştır. İçerik analizi farklı yöntemlerle elde edilen verilerin belirlenen temalar etrafında özetlenmesi ve yorumlanmasına dayanır (Özdemir 2010). Çalışmada her bir alt problem kendi içerisinde ayrı ayrı gruplandırılmıştır. Öncelikle her bir sınıf kendi içerisinde ayrılmıştır. Sonrasında sorulara verilen cevaplar nitel gruplar altında toplanmıştır. Belirlenen gruplarda her bir kategorinin tekrar edilme durumu incelenmiş ve belirlenen tekrar durumları frekanslandırılmıştır. Çalışmanın sonraki aşamasında veriler her bir alt problem için tablolaştırılmıştır. Son aşamada tablolar yardımı ile veri yazıya dönüştürülmüştür. Verilerin yazıya dönüştürülmesinde hem geçerlilik ve güvenilirliği arttırmak hem de kategori ve grupların anlaşılmasını kolaylaştırmak amacıyla öğrenci cevaplarından direkt alıntılara yer verilmiştir. 


\section{Bulgular}

Bu kısımda hazırlanan açık uçlu ankete öğrenciler tarafından verilen cevaplar kategorilendirilerek sunulmuştur. Bulgular dört alt başlık halinde incelenmiştir.

\section{Eski uygarlıkların bilime katkılart}

$\mathrm{Bu}$ kısımda öğrenciler tarafından ifade edilen ilk uygarlıklar ve bu uygarlıkların bilim dünyasına katkıları sunulmuştur. Soruya 9. sınıf öğrencilerinden 3 boş, 7 geçersiz yanıt verilirken, 10. sınıfta 11 boş 22 öğrenci geçersiz cevap verilmiştir.

\begin{tabular}{|c|c|c|c|c|c|c|c|}
\hline Uygarlık & $\begin{array}{l}\text { Bilime } \\
\text { katkı }\end{array}$ & $\begin{array}{l}\text { 9. Sinif } \\
\%\end{array}$ & $\begin{array}{l}\text { 10. sinif } \\
\%\end{array}$ & Uygarlık & Bilime katkı & $\begin{array}{l}\text { 9. Sinif } \\
\%\end{array}$ & $\begin{array}{l}\text { 10. sinif } \\
\%\end{array}$ \\
\hline \multirow{8}{*}{ Sümerler } & Yaz1 & 40 & 5 & Çin & Barut & 20 & 9 \\
\hline & Tekerlek & 6 & 14 & & Pusula & 13 & 9 \\
\hline & $\begin{array}{ll}\text { Ay } & \text { y1lı } \\
\text { esaslı } & \\
\text { takvim } & \\
\end{array}$ & 6 & & & Kağıt & 6 & 4 \\
\hline & $\begin{array}{l}\text { Dairenin } \\
360^{\circ} \text { oluşu* }\end{array}$ & 3 & & & Matbaa & 3 & 2 \\
\hline & Ateş* & & 2 & & Havai fişek & 3 & \\
\hline & Para* & 3 & 2 & & Mürekkep & 3 & \\
\hline & Aritmetik & 3 & & & Takvim & & 2 \\
\hline & Geometri & 6 & & Misir & Pi sayıs1* & 13 & \\
\hline \multirow[t]{2}{*}{ Lidya } & Para & 26 & 14 & & Takvim & 10 & 9 \\
\hline & Yaz1* & 6 & & & Güneş saati & 10 & 2 \\
\hline \multirow[t]{2}{*}{ Fenikeliler } & Cam & 10 & 2 & & Para* & & 2 \\
\hline & Alfabe & 3 & & & Matematik & & 2 \\
\hline \multirow[t]{5}{*}{ Türkler } & Tip & & 5 & & Tip & & 4 \\
\hline & Matematik & & 4 & & Pusula* & & 2 \\
\hline & Astronomi & & 4 & Babil & Tip & 10 & \\
\hline & Fizik & & 4 & Yunan & Tip & & 2 \\
\hline & Coğrafya & & 2 & & Heykel & & 2 \\
\hline Asur & Kütüphane & 10 & & Aztek & Mürekkep* & & 4 \\
\hline İngiliz & Telefon** & & 4 & İnka & Çikolata* & & 2 \\
\hline
\end{tabular}

Tablo 2. Öğrenciler tarafından ifade edilen uygarlıkların bilime katkıları [* Öğrenciler tarafından ifade edilen yanlış bilgiler; ** Yanlış kategoride yer alan bilgiler]

Tablo 2'e göre uygarlıkların bilime katkıları değerlendirildiğinde Çinlilere ait 6, Sümerler ve Türklere ait 5, Misırlılara ait 4, Fenikeliler ve Yunanlılara ait 2, Lidya, Asur ve Babil uygarlıklarına ait 1 bilimsel katkı kategorisi ortaya çıkmıştır. 
Öğrenciler tarafından en fazla ifade edilen Sümerler tarafından yazının (\% 40) ve tekerleğin (\% 14) bulunması, Lidyalıların parayı bulması (\% 26) ve Çinliler tarafından Barut (\% 20) ve pusulanın (\%13) bulunması bilgisidir.

Türklerin coğrafya alanına katkısı, Çinlilerin havai fişek, mürekkep ve takvimi bulmaları, Mısırlıların Matematik, Babillerin tıp, Yunanların tıp ve heykelcilik alanındaki katkıları yalnızca bir öğrenci tarafından ifade edilmiştir.

Bununla birlikte öğrenciler tarafından yanlış ifade edilen bilgiler Sümerlerin dairenin $360^{\circ}$ oluşunu, ateşi ve parayı, Lidyalıların yazıyı, Mısırlıların Pi sayısını, parayı ve pusulayı, Azteklerin mürekkebi ve İnkaların çikolatayı bulması şeklindedir.

Öğrenciler tarafından verilen cevaplarda Fizik alanı ile ilişkili olarak ilk uygarlıkların buluşları; Sümerlerin ay yılı esaslı takvimi, Türklerin fizik alanına katkı sağladığı, Mısırlıların takvim ve güneş saatini bulmasıdır.

\section{Bilim insanlarının bilime katkılart}

$\mathrm{Bu}$ kısımda öğrencilerin bilim insanlarının hangi alanda bilime ne gibi katkılarda bulunduklarına yönelik verdikleri cevaplara ait bulgular yer almaktadır. Bu kategoride yer alan soru 9. Sınıfta sadece 2 öğrenci tarafından boş bırakırken, 10 sınıfta 5 öğrencinin cevabı boş, 9 öğrencinin cevabı geçersiz sayılmıştır.

\begin{tabular}{|c|c|c|c|c|c|c|c|}
\hline Bilim insanı & Bilime katkı & $\begin{array}{l}9.5 \\
\%\end{array}$ & $\begin{array}{l}\text { 10.s. } \\
\%\end{array}$ & Bilim insanı & Bilime katkı & $\begin{array}{l}\text { 9.s. } \\
\%\end{array}$ & $\begin{array}{l}\text { 10.s. } \\
\%\end{array}$ \\
\hline Newton & Yerçekimi & 60 & 7 & Edison & Ampul & 66 & 44 \\
\hline \multirow[t]{4}{*}{ Einstein } & $\begin{array}{l}\text { Atomun } \\
\text { parçalanabileceği }\end{array}$ & 23 & 12 & & Telefon* & 3 & 4 \\
\hline & Elektrik* & & 4 & Pasteur & Pastörizasyon & 20 & 2 \\
\hline & Atom bombas1* & & 4 & & Kuduz aş1sı & & 2 \\
\hline & & & & Galileo & Teleskop & 20 & 2 \\
\hline \multirow[t]{2}{*}{ Graham bell } & Telefon & 26 & 37 & & $\begin{array}{l}\text { Dünyanın } \\
\text { yuvarlak old. }\end{array}$ & 3 & \\
\hline & Ampul* & & 5 & Hook & Hücre & 10 & \\
\hline Dalton & Atom modeli & 10 & & Tesla & Elektrik & & 4 \\
\hline Toriçelli & Açık hava basıncı & 3 & & Piri Reis & Dünya haritası & & 6 \\
\hline $\begin{array}{l}\text { Antoine- } \\
\text { Laurent de } \\
\text { Lavoisier }\end{array}$ & $\begin{array}{l}\text { Kütlenin korunumu } \\
\text { kanunu }\end{array}$ & 6 & & Joseph Proust & $\begin{array}{ll}\text { Sabit } & \text { oranlar } \\
\text { kanunu } & \end{array}$ & 10 & \\
\hline
\end{tabular}




\begin{tabular}{|c|c|c|c|c|c|c|c|}
\hline İbni sina & Tip & & 28 & Harezmî & Sifir sayıs1 & 3 & 4 \\
\hline $\begin{array}{l}\text { Amedeo } \\
\text { Avogadro }\end{array}$ & $\begin{array}{l}\text { Aynı sıcaklıkta eşit } \\
\text { hacimdeki gazlar eşit } \\
\text { sayıda molekül içerir }\end{array}$ & 6 & & Macellan & $\begin{array}{l}\text { Dünyanın } \\
\text { yuvarlaklığı }\end{array}$ & & 2 \\
\hline Guericke & Hava pompası & 6 & & Ömer Hayyam & Celali takvimi & & 4 \\
\hline Ohain & Jet uçağ1* & 6 & & Melikşah & Takvim* & & 2 \\
\hline Rice & Hoparlör & 6 & & $\begin{array}{l}\text { Hezarfen } \\
\text { Ahmet Çelebi }\end{array}$ & $\begin{array}{l}\text { kendi geliştirdiği } \\
\text { takma kanatlarla } \\
\text { uçmayı başarmış }\end{array}$ & & 2 \\
\hline Harrison & Kronometre & 6 & & Ali Kuşçu & $\begin{array}{l}\text { gök cisimlerinin } \\
\text { Dünyaya } \\
\text { uzaklıkları }\end{array}$ & & 2 \\
\hline Berliner & Mikrofon & 6 & & Biruni & $\begin{array}{l}\text { Işı hızının ses } \\
\text { hızından fazla } \\
\text { old. }\end{array}$ & & 4 \\
\hline Daimler & Motosiklet & 6 & & Hasan çelebi & Fişek* & & 2 \\
\hline Marconi & Radyo & 6 & & Battani & $\begin{array}{l}\text { Zic (astronomik } \\
\text { cetvel) }\end{array}$ & & 2 \\
\hline Goddart & Roket & 6 & & $\begin{array}{l}\text { Wright } \\
\text { Kardeşler }\end{array}$ & Uçak & & 2 \\
\hline Poulsen & Teyp kayd1 & 6 & & Fezari & Usturlap & & 2 \\
\hline Robert Boyle & Boyle yasası & 3 & & Biruni & $\begin{array}{l}\text { Dünyanın } \\
\text { yarıçapı }\end{array}$ & & 2 \\
\hline Archimedes & Spiral bomba* & 3 & & $\begin{array}{l}\text { Şerefettin } \\
\text { Sabunculoğlu }\end{array}$ & Tip & & 2 \\
\hline & Küre hacmi & 3 & & & & & \\
\hline
\end{tabular}

Tablo 3. Bilim insanlarının bilime yaptığı katkılar [*Öğrenciler tarafından ifade edilen yanlış bilgiler]

Tablo 3. İncelendiğinde öğrenciler tarafından en fazla ifade edilen bilim insanları ve bilime katkıları Edison'un ampulü (\%66 ve \%44), Newton’un yerçekimini (\%60 ve \%7), Graham Bell’in telefonu (\%26 ve \%37), Galileo'nun teleskopu bulması (\%20 ve \%2) ve İbni sina'nın tıp alanında (\%28) çalışmasıdır.

Birden fazla öğrenci tarafindan Dalton'un atom modelini, Antoine-Laurent de Lavoisier'in Kütlenin korunumu kanunu, Amedeo Avogadro'nun aynı sıcaklıkta eşit hacimdeki gazların eşit sayıda molekül içerdiği, Guericke'nin hava pompasını, Rice'nin hoparlörü, Harrison'un kronometreyi, Berliner'in mikrofonu, Daimler'in motosikleti, Marconi'nin radyoyu, Goddart'ın roketi, Poulsen'in teyp kaydını, Pasteur'ün pastörizasyonu, Hook’un hücreyi, Tesla'nın elektriğgi, Piri Reis'in dünya haritasını, Joseph Proust'un sabit oranlar kanununu, Harezmî'nin sıfır sayısını, Macellan'ın dünyanın yuvarlak olduğunu, Ömer Hayyam'ın Celali takvimini ve Biruni’nin ışık hızının ses hızından fazla olduğunu bulduğunu söylemişlerdir. 
Cevaplarda dikkat çeken yanlış bilgiler; Einstein'in elektriği (\%4) ve atom bombasını (\% 4), Edison'un telefonu (\%3 ve \%4), Graham Bell'in ampulü (\%5), Ohain'in jet uçağı (\%6), Melikşah'ın takvimi (\%2), Hasan Çelebi'nin fişeği (\%2) ve Archimedes'in spiral bombayı (\%3) bulmasıdır.

Bilim insanları ve buluşları incelendiğinde fizik alanında çalışma yürüten bilim insanları ile ilgili olarak; Newton'un yerçekimini (\%60 ve \%7), Einstein'in atomun parçalanabileceğini (\%23 ve \%12), Graham Bell'in telefonu (\%26 ve \%37), Dalton'un atom modelini (\%10), Toriçelli'nin açık hava basıncını (\%3), Antoine-Laurent de Lavoisier'in kütlenin korunumu kanununu (\%6), Edison'un ampulü (\%66 ve \%44), Galileo'nun teleskopu (\%20 ve \%2) ve dünyanın yuvarlak olduğunu (\%3), Biruni'nin 1şık hızının ses hızından fazla olduğunu (\%4) ve dünyanın yarıçapını tespit ettiği (\%2), Battani'nin zic adı verilen astronomik bir cetveli bulduğunu (\%2) ve Ferazi'nin usturlabı (\%2) keşfettiği belirtilmiştir.

Fizik dersi açısından bahsedilen bilim insanları incelendiğinde Newton'un hareket kanunlarında Newton (22) ve Biruni (2), elektrikte Edison (45) ve Tesla (2), madde ve özelliklerinde Toriçelli (1), atom teorilerinde Einstein (14) ve Dalton (3) ve astronomide Biruni (1), Fezari (1), Battani (1) ve Galileo'dan (8) bahsedilmiştir.

\section{Buluşların zaman içerindeki gelişimi}

$\mathrm{Bu}$ kısımda öğrencilerden günümüzde kullandığımız buluşların zaman içerisindeki gelişimi hakkında bilgi vermesi istenmiştir. Soruya 9.9 Sınıf öğrencilerinden 5’i boş cevap verirken, 5 öğrencinin cevabı da geçersiz sayılmıştır. 10 sınıfta 13 boş, 9 geçersiz cevap bulunmaktadır.

\begin{tabular}{|l|l|l|}
\hline Buluş & 9. sinıf \% & 10. sınıf \% \\
\hline Telefon & 23 & 35 \\
\hline Bilgisayar & 26 & 14 \\
\hline Tekerlek & 13 & 10 \\
\hline Arabalar & 10 & 8 \\
\hline Lamba & 10 & 5 \\
\hline Televizyon & 3 & 4 \\
\hline
\end{tabular}




\begin{tabular}{|l|l|l|}
\hline Elektrik (Edison- tesla) & & 5 \\
\hline Ak1llı tahta & 6 & \\
\hline Tren & 3 & \\
\hline Çamaşır makinesi & 6 & \\
\hline Top & & 4 \\
\hline Matbaa & & 2 \\
\hline Radyo & & 2 \\
\hline
\end{tabular}

Tablo 4. Buluşların zaman içerisindeki gelişimi

Tablo 4. incelendiğinde öğrencilerin en fazla telefonun zaman içerisindeki gelişiminden bahsettikleri (\%23 ve \%35) ortaya çıkmıştır. Bunun yanında bilgisayarın gittikçe küçülmesi ve işlem kapasitesinin artması ve tekerleğin gelişerek uçak ve otomobillerde daha güçlü şekilde kullanılması ifade edilen diğer buluşlardır. Arabalarda zamanla daha teknolojik aletlerin kullanılması, lambaların enerji ve aydınlatma yönünden gelişmesi, televizyonlarda görüntü ve hacmin azalması her iki sınıf öğrencileri tarafından belirtilen diğer gelişmelerdir. Yalnızca 9. Sınıf öğrencileri tarafından akıllı tahtalardaki gelişmeler, kara trenlerden hızlı trenlere geçişler ve merdaneli makinelerden tam otomatik çamaşır makinelerine geçişler ifade edilmiştir. Yalnızca 10. Sınıf öğrencileri Edison’dan sonra Tesla'nın elektriği geliştirdiğini, hayvan derilerinden plastiktik toplara geçişi, matbaanın ve radyonun gelişimini belirtmişlerdir. Aşağıda bazı öğrenciler tarafından soruya verilen cevaplara ait örnekler yer almaktadır.

"Lambalar günden güne değişerek daha fazla 1şık ve daha az elektrik harcayacak şekle dönüştü’”(9. sınıf) (Lamba)

"Televizyonlar eskiden tüplüydü, şimdi plazma televizyonlar üretilmiş, hem az yer kapliyor hem de daha az enerji harciyor." (9. sinıf) (Televizyon)

"bilgisayarın yıllar içindeki değişimi buna örnektir. Bilgisayarın ilk halleri büyük ve bir oda kadardı. Ama şimdi küçük ve her yere taşınabiliyor" (9. sınıf) (Bilgisayar)

"Edison ampulü bulmuş, Tesla geliştirmiş ve daha sonra floresan lambalar üretilmiştir.” (10. sınıf) (Lamba)

"Tekerlek önceden taştan tahtadan yapıllyor günümüzde ise lastik kauçuktan yapılıyor hatta gittikçe daha kaliteli lastikler kullanılıyor" (10. sınıf) (Tekerlek)

"Telefon önceden tuşluydu, sonra kameralı oldu ve en sonunda dokunmatik oldu" (10. sinif) (Telefon)

"Radyolar önceden boyut olarak büyük ve iriydi, bir yere götürmemiz zor oluyordu. Şimdi ise mp3'ler, akıllı telefonlar yardımıyla her yerde rahatlıkla kullanabiliyoruz." (10. sinif) (Radyo) 


\section{Buluşların ortaya çıkışı hakkında bilinen hikâyeler}

$\mathrm{Bu}$ kısımda öğrencilerden buluşların ortaya çıkmasında veya gelişmesinde bildikleri hikayeleri yazmaları istenmiştir. Bu soruya 9. Sınıfta 14 boş 9 geçersiz cevap verilirken, 10. Sınıfta 23 boş, 17 geçersiz cevap verilmiştir. Öğrencilerin cevaplarının kategorilere göre dağılımı ve frekans değerleri tablo 5'te yer almaktadır.

\begin{tabular}{|l|l|l|l|}
\hline Buluş & & 9. sinıf & 10. sınıf \\
\hline Graham Bell & Telefonda sevgilisinin adını kısaltması & 6 & 10 \\
\hline Newton & Başına elma düşmesi & 9 & 7 \\
\hline Archimedes & Banyoda suyun kaldırma kuvvetini bulması & 2 & 4 \\
\hline Edison & Edison tesla çekişmesi & & 2 \\
\hline Edison & $\begin{array}{l}\text { Elektriği icat ederken çok fazla deney yapıp } \\
\text { yanlış yolları öğrenmesi }\end{array}$ & 2 \\
\hline Einstein & Yanlışlıkla atom bombasını bulması* & 2 & \\
\hline
\end{tabular}

Tablo 5. Öğrenciler tarafından ifade edilen buluşların ortaya çıkış hikâyeleri [*Öğrenciler tarafından ifade edilen yanlış bilgiler]

Öğrenciler tarafında en fazla ifade edilen hikâye Graham Bell'in telefonda konuşurken sevgilisinin adını kısaltması ve buradan alo sözcüğünün türemesidir (\%6 ve \%10). Bunun dışında en fazla belirtilen bir diğer hikâye Newton'un elma ağacının altında otururken başına elma düşmesi sonucu yer çekimini bulmasıdır (\%9 ve \%7). Arcimedes'in banyo tasının suda yüzmesi sonucu suyun kaldırma kuvvetini keşfetmesi ifade edilen başka bir hikâyedir (\%2 ve \%4). Edison ve Tesla arasında ekonomik çıkarlara dayalı çekişmeler (\%2) ve Edison'un ampulün icadında çok fazla deney yapmasına karşın sonuca ulaşamaması neticesinde hangi denemelerin sonuca götürmeyeceğini öğrendim demesi Edison'la ilgili ifade edilen hikâyelerdir. Einstein'in yanlışlıkla atom bombasını bulduğunu söylemesi ise öğrenci tarafından ifade edilen yanlış bir hikayedir. Aşağıda bazı öğrencilerin bu soruya verdikleri cevaplara ait alıntılar yer almaktadır.

"Alexander Graham Bell telefonu icat ettikten bir süre sonra sevgilisi onu terk etti ve o günden sonra Graham Bell telefonu her açtığında sevgilisinin adının ilk harflerini söyledi. 'ALO' Alexander Lolita Ozvald" (9. sinıf)

"Newton bir gün ağacın altında otururken kafasına elma düşer. $\mathrm{Bu}$ olay Newton'un dikkatini çeker ve araştırarak yer çekimini bulur." (9. sınıf)

"Edison ampulün bulunuşunda birçok yol denemiş ve başarısız olmuştur. Bir kişinin bunca deneme yaptınız ama hiçbir işe yaramadı, elinize hiçbir şey geçmedi demesi üzerine ben ampulün bulunuşunda bu yolların doğru olmadığını farklı bir yolla ampülün bulunacağını keşfettim demiştir.” (10. sınıf) 
"Birinden telefon geldiğinde açıp ALO diyoruz. Çünkü Graham Bell telefonu her açtığında onu terk eden sevgilisinin aradığını düşünmüş ve onun ismini söylemiş, çok uzun olduğu için kısaltarak ALO demiştir.”(10. sınıf)

"Edison ampulü bulmak için Tesla'nın çalışmalarından yararlanmıştır. Hatta onları kendi çıkarları için kullanmıştır.” (10. sınıf)

"Archimedes bir gün hamamda banyo yaparken tasın suda batmadığını fark ediyor. Suyun kaldırma kuvvetini bulduğu için buldum, buldum diye bağırarak dışarı çıkıyor" (10. sınıf)

\section{Tartışma ve Sonuç}

Bilim tarihi, bilimin gelişimi ve bilim insanına yönelik bilgilerin incelendiği bu çalışmada 9 ve 10. sınıfta öğrenim gören öğrencilerin yüzeysel ve basmakalıp bilgilere sahip olduğu ortaya çıkmıştır. Verilen örnekler günlük yaşamda, medyada ve ders kitaplarında sıklıkla karşılaşılan açıklamalardır. Benzer olarak farklı araştırmacılar tarafından da bilim tarihine yönelik yürütülen çalışmalarda öğrencilerin bilgilerinin yetersiz olduğuna vurgu yapılmaktadır (Laçin Şimşek 2011b: 133; Kapucu ve Çılgın 2016: 344). Öğrencilerin derste iki önemli bilgi kaynağından biri öğretmenler tarafından kullanılan ders kitapları, diğeri ise öğretmenlerin sınıf içi uygulamalarıdır (Kapucu ve Çılgın 2016: 332). Ders kitapları incelendiğinde bilim tarihine yönelik yeterli bilginin ders kitaplarında bulunmadığı açıktır (Kahraman 2013: 71; Kılıç 2010: 72; Yıldız 2013: 97). Bunun yanında Fen bilimlerine ait ders kitaplarında bilim tarihine yönelik yeterli özenin gösterilmediği kavramsal ve prosedürel açıdan bilim tarihine yönelik metinlerin yerleştirildiği ancak bunun da yeterli olmadığı bilinmektedir (Koçyiğit ve Pektaş 2017: 195). Durum öğretmenler açısından da faklı değildir. Öğretmenlerin bilim tarihini programa entegre edemedikleri için öğrencilere bu konuları aktaramadıkları bilinmektedir (Tamir 1989: 98; Susam 2007: 41). Öğretmen adayları ile yürütülen çalışmalarda da adaylar yeterli bilgi düzeyine sahip olmadığı ortaya çıkmıştır (Laçin Şimşek ve Şimşek 2010: 194, Abd-El-Khalick ve Lederman 2010: 694). Ayrıca öğretmenler öğretim materyallerinin yetersizliği veya bilgi eksikliği gibi nedenlerle derslerinde bilim tarihine vurgu yapamamaktadırlar (Susam 2007: 41). Öğretmenler derslerinde bilim tarihinden yararlanmamalarının nedenini ise mevcut programda bilim tarihine yönelik kazanımların bulunmamasına bağlamaktadırlar (Laçin Şimşek 2011c: 
733). Oysa gerek fen bilimlerinde gerekse fizik derslerinde yenilenen müfredatlarla birlikte azda olsa bilim tarihi kazanımlarına yer verilmiştir (Kandil İngeç vd. 2016: 182). Ancak kazanımlarda belirtilmesine rağmen ders kitapları hazırlanırken gerekli özen gösterilmemiş ve bilim tarihine yönelik bilgiler ders kitaplarına eklenmemiştir (Koçyiğit ve Pektaş 2017: 195). Öğrencilerin bilim tarihi konusunda yeterli düzeyde bilgi sahibi olamamalarının başka bir nedeni ise öğretmenlerin tutumlarına bağlı olabilir. Çünkü öğretmenlerin derslerde bilim tarihine önem vermemesi de bilim tarihine yönelik algıyı etkilemekte ve bu alanda öğrenciler yeterli düzeyde bilgiye sahip olamamaktadır (Kapucu ve Çıılgın 2016: 332).

İlk insanların bilime katkılarına yönelik bulgular incelendiğinde öğrencilerin genellikle Sümerlerin yazıyı, Lidyalıların parayı, Çinlilerin barut ve pusulayı ve Misırlıların takvimi bulduğu yönünde bilgi beyan ettikleri görülmektedir. Bu durum tek yönlü bilim anlayışının bir yansıması olarak düşünülebilir (Laçin Şimşek 2011b: 120). Burada dikkat çeken konu ilk uygarlıkların bilime katkıları belirtilmesine rağmen sonrasında bir dönemin kesintiye uğrayarak rönesansla bilimin tekrar yükselişe geçtiğine yönelik düşüncedir (Laçin Şimşek 2011a: 156). Verilen cevaplarda da sadece Mısır, Sümer, Çin gibi uygarlıklardan bahsedilmiş, sonrasında bilimin sekteye uğradığına yönelik bir algının oluşmasına neden olmuştur. Ancak bu gelişmelerin akabinde 16. Yüzyıla kadar bilim Türk- İslam bilginleri ile gelişme göstermiş ve bu yıllarda temeli atılan bilgiler sayesinde bu günkü bilimsel bilgilere ulaşılmıştır (Morgil 1990: 21). Verilen cevaplarda da çok az öğrencinin Türk- İslam dünyasının da bilime katkı yaptığını belirttiği görülmektedir. Ne yazık ki öğretim programlarında Birûni, Fergânî, Ebü’l Vefa, Uluğ Bey ve Ali Kuşçu gibi ünlü Türk- İslam bilginleri ve bunlara ait buluşlar kısaca söz edilerek geçilmektedir (Dayday ve Altın 2010: 13). Bu durum çok az öğrencinin Türk- İslam bilginleri hakkında bilgi sahibi olmasının nedenini açıklamaktadır. Oysa öğrencilerin Türk- İslam bilginleri hakkına bilgi sahibi olmaları kendi kültürlerinden haberdar olmalarını ve biliminin evrenselliğini anlamalarına katkı sağlayacaktır. Bunun yanında bilimi sevmelerinin ve bu insanlardan esinlenerek bilime karşı olumlu tutum geliştirebilmelerinin yolu açılacaktır. 
Öğrenciler Newton'un hareket kanunları, elektrik ve manyetizma, atom teorileri, madde ve özellikleri ve astronomi üniteleri içerisinde yer alan konularda bilime katkı yapan bilim insanlarından söz etmişlerdir. 9. Sınıfta enerji ve 1sı sıcaklık, 10. Sınıfta basınç ve kaldırma kuvveti, dalgalar ve Optik ünitelerine yönelik hiçbir bilim insanının katkısından söz edilmemiştir. Program incelendiğinde bu ünitelerde de bilim tarihine ve bilim insanlarının buluşlarına yönelik bilgiler yer almaktadır (Kandil İngeç vd. 2016: 178). Örneğin kazanımlarda ve ders kitaplarında Anomon'un deneyi, Gelileo'nun kemik yapılarının dayanıklılı̆̆ı ve eğik düzleme yönelik deneylerinden bahsedilmektedir (MEB 2013: 6). Ancak hiçbir öğrencinin bu konuda bir açıklama yapmaması şaşırtıcıdır. Bu durumun bir nedeninin öğretmenlerin bilim tarihine yeterince vurgu yapmamalarından kaynaklanabileceği düşünülebilir. Fen bilgisi öğretmenleri ile yürütülen bir çalışmada da öğretmenlerinin çoğunun derslerinde bilim tarihine yer vermedikleri belirtilmektedir (Laçin Şimşek 2011c: 737). Bunun yanında her iki sınıfta da yer almayan atom teorileri ünitesine yönelik olarak Einstein ve Dalton ve astronomi ünitelerine yönelik olarak Türk İslam bilginleri ve Galileo'dan söz edilmiştir. Öğrencilerin bu bilim insanlarını bilmeleri fizik bilimine giriş ünitesinde bunlarla karşılamalarından veya tarih derslerinde bilim tarihine yönelik bilgiler almalarından kaynaklanabilir. İmamoğlu ve Çeken (2001: 84) tarafından fen bilgisi ve sosyal bilgiler programlarının bilim tarihi yönünden karşılaştırılmasında her iki programın da birbirleri ile ilişkilendirilebilecek kazanımlar içerdiği belirlenmesi bu durumu destekler niteliktedir. Bunun yanında fizik bilimine giriş ünitesinde bilim tarihine daha fazla yer verilmesi ve diğer ünitelere oranla bu ünitede daha fazla bilginin bulunması (Kandil İngeç vd. 2016: 182), öğrencilerin bilim tarihine yönelik farklı bilgileri ortaya koymalarının bir nedeni olarak gösterilebilir. Öğrenciler tarafından verilen cevapların bu bilgilerin de etkisinde kalınarak verilebileceği düşünülmektedir. Bu uygulamalarla öğrencilerin sadece fizik alanında değil astronomi, tıp, kimya gibi alanlarda da buluşları öğrenmelerinin yolu açılabilir.

Öğrenciler tarafından en fazla bulgu elde edilen alan bilim insanları ve bunların buluşlarına yönelik bilgilerdir. Bilim tarihinden yaralanan öğretmenlerin daha çok bilim 
insanları ve bilime yaptıkları katkılar vasıtası ile bilim tarihinden yararlandıkları belirtilmektedir (Laçin Şimşek 2011c: 733). Bu durum öğrencilerin bilim insanları ve icatları konusunda diğer alanlara göre daha fazla bilgi vermelerinin bir nedeni olarak ifade edilebilir. Bu bilim insanlarından en çok Newton, Einstein, Graham Bell ve Edison'dan söz etmektedirler. Benzer çalışmalarda da öğrencilerin sıklıkla ifade ettikleri bilim insanları Newton, Einstein ve Galieo'dur (Kapucu ve Çılgın 2016: 335). Bu durumun bir nedeni ders kitaplarında bilim tarihine yeterince önem verilmemesinden kaynaklanabileceği gibi, popüler kitaplarda ve günlük yaşamda da bu sadece örneklerle karşılaşmalarından kaynaklanabilir (Laçin Şimşek 2011b: 133). Bu durumun başka bir nedeni ise y1llarca eğitim sistemi içerisinde klişeleşmiş bilgilerin öğrencilerin ilk aklına gelen bilgiler olmasından kaynaklanabilir. Müfredatta yapılan yeniliklerin ve değişimlerin sonuçlarının hemen görülmesi beklenemez. Bu değişim biraz zaman alması ve öğrencilerin ve öğretmenlerin zihinlerinde oturması için yeni ve farklı adımların da atılması gerekebilir. Bilim tarihine yönelik bilgiler incelendiğinde hem bilim insanları, hem de uygarlıkların bilime katkıları yönünden bazı öğrencilerin yanlış ve eksik fikirlere sahip olduğu ortaya çıkmıştır. Bu durum öğrencilerin bilim tarihi konusunda yeterli bilgiye sahip olmadıklarının başka bir kanıtı olarak gösterilebilir.

Buluş icat ve kavramların tarihsel gelişimine bakıldığında herhangi bir bilimsel açıklamaya yönelik bir bilginin olmadığı ortaya çıkmaktadır. Öğrenciler yalnızca günlük yaşamda kullanılan cihazların gelişiminden bahsetmiştir. Oysa atom teorileri, elektriğin keşfi ve gelişimi gibi bilimsel kavramların zaman içerisindeki gelişiminden bahseden öğrenci yok denecek kadar azdır. Buna karşın derslerinde bilim tarihine yer veren fen bilgisi öğretmenlerinin derste en sık bilim, icat ve buluşların tarihsel gelişimine yer verdiklerini söylemeleri bu bulgu ile çelişki göstermektedir (Laçin Şimşek 2011c: 733). Aynı şekilde biyoloji ders kitapları ile yürütülen bir çalışmada da ders kitaplarında yer alan bilim tarihine yönelik bilgilerinin bilginin sürekli değişim ve gelişim sürecini anlamaya yetecek düzeyde tasarlandığı belirtilmektedir (Yıldız 2013: 94). Bu çalışmada ise herhangi bir bilimsel bilginin gelişiminin ortaya koyulmaması ya öğretmenlerin bu alanlardan bahsederek önemsememelerinden veya öğrencileri ders 
kitaplarına yönlendirmemelerinden, bunun yerine üniversite sınav odaklı bir öğretim gerçekleştirmelerinden kaynaklanabilir. Bunun yanında bilimsel çalışmaların gelişimi incelendiğinde bilimsel bilgilerin gelişiminin öğrencilerde oluşan bilim kavramları ile paralellik gösterdiği bilinmektedir. Bu nedenle bilimsel kavramların gelişimini bilen öğrenci zihninde daha rahat yanlış anlamaları ve kavram yanılgılarını giderebilir. $\mathrm{Bu}$ açıdan bakıldığında ise bilimin tarihsel gelişiminin öğrencilere oluşan kavram yanılgılarının giderilmesinde yardımcı olabileceği düşünülebilir.

Bilimsel hikâyelere yönelik bilgiler incelendiğinde öğrencilerin herkes tarafindan bilinen hikayeleri yazdıkları görülmektedir. Oysa fizik kazanımları içerisinde Faraday kafesinin ortaya çıkışı veya iletken ve yalıtkan kavramlarının doğuşuna yönelik bilgilerin olması gerektiği vurgulanmaktadır (MEB 2013: 13). Benzer olarak Metz vd. (2007: 317)'de herhangi bir bilimsel alt yapısı olmayan ve Fen'e karşı ilgisi az olan öğrencilerin bile Newton'un elması veya Arşimet'in hamam hikâyesini bildiğini söylemiştir. Öğrencilerin bu bilgileri bilmeleri günlük yaşantılarda da bu tür hikâyelerle karşılaşmalarından kaynaklanabilir (Laçin Şimşek 2009: 143). Bilim insanlarına yönelik elde edilen bilgiler daha çok kulaktan dolma bilgilerdir (Kaya vd. 2013: 318). Bu bilim insanları hakkında verilen hikâyeler bile yeterince açık ve kapsamlı bir şekilde açıklanamamıştır. Fen bilimleri ders kitaplarında yer alan okuma parçalarında da bilim tarihine özen gösterilmemiş bir şekilde ve bilim tarihine yönelik bahsedilen kazanımları karşılayamayacak düzeyde hazırlanmışlardır (Koçyiğit ve Pektaş 2017: 195). Fizik ders kitaplarında bilim insanlarının kişilikleri ve çok yönlülüklerine yönelik yeterince vurgu yapılmadığı bilinmektedir (Kandil İngeç vd. 2016: 182). Oysa bu tür anekdotlar hem öğrencilerin derse ilgilerinin canlı tutulmasına ve dikkat çekici olmasına, hem de bilimsel bilgiye yönelik incelemelerin sağlanmasına yardımcı olmasına katkıları bulunabilir. $\mathrm{Bu}$ açılardan bakıldığında bilimsel hikâyeler farklı birçok yöntemle birleştirilerek etkili ve verimli öğretimin yolu açılabilir.

$\mathrm{Bu}$ çalışma sonucunda öğrencilerin bilim tarihine yönelik yeterli bilgiye sahip olmadığı ortaya çıkmıştır. Bu durumun geliştirilmesi için öğretmenlerin öncelikle bilinçlendirilmesi ve bilgilendirilmesi gerekmektedir. Öğretmenlerin bu konudaki bakış 
açıları ve farklı yöntemlerle bilim tarihinden derslerde yararlanmaya yönelik yürütülen çalışmalarla öğrencilerin bu konu hakkındaki bilgilerinin gelişimi sağlanabilir. Bunun yanında bilim tarihini sadece fen bilimleri alanında yürütülecek çalışmalar olarak düşünmemek gerekir. Farklı disiplinlerin ve alanların etkileşimi ve bu alanlarda yürütülen çalışmaların da bireylerin bilim tarihi konusunda gelişimine katkı yapacağı unutulmalıdır. $\mathrm{Bu}$ nedenle bilim tarihine yönelik çoklu disiplinli çalışmaların yürütülmesi önerilmektedir. 


\section{KAYNAKÇA}

ABD-EL-KHALICK, Fouad and Norman G. LEDERMAN (2000). "Improving Science Teachers Conceptions of Nature of Science: A Critical Review of the Literature", International Journal of Science Education, 22(7): 665-701.

American Association for the Advancement of Science (AAAS) (1993). Benchmarks for science literacy. New York: Oxford University Press. (https://www.aaas.org/).

AYVACI, Hakan Şevki (2007). Bilimin Doğasının Sınıf Öğretmeni Adaylarına Kütle Çekim Konusu İçerisinde Farklı Yaklaşımlarla Öğretilmesine Yönelik Bir Çalışma, (Yayınlanmamış Doktora Tezi), Karadeniz Teknik Üniversitesi, Fen Bilimleri Enstitüsü, Trabzon.

ÇEPNİ, Salih (2007). Araştırma ve Proje Çalışmalarına Giriş, (Genişletilmiş 3. Baskı.), Trabzon: Celepler Yayıncılık.

DAYDAY, Necmi ve Vural ALTIN (2010). Gök Biliminde Türk-İslâm Bilginleri, İstanbul: Türksat Yayınları.

DOĞAN BORA, Nihal, ARSLAN, Orhan ve Jale ÇAKIROĞLU (2006). "Lise Öğrencilerinin Bilim ve Bilim İnsanı Hakkındaki Görüşleri”, Hacettepe Üniversitesi Ĕ̈itim Fakültesi Dergisi, 31: 32-44.

İMAMOĞLU, Hüseyin Vehbi ve Ramazan ÇEKEN (2001). "İlköğretim Sosyal Bilgiler Dersinin Bilim Tarihi Açısından Fen ve Teknoloji Dersi İle İlişkilendirilmesi Üzerine Disiplinlerarası Bir Bakış", ODÜ Sosyal Bilimler Enstitüsü Sosyal Bilimler Araştırmaları Dergisi, 2(3): 71-87.

KAHRAMAN, Burçin (2013). Genel Kimya Ders Kitaplarında "Kuantum Sayıları" Konusunun Sunumu: Bilim Tarihi ve Felsefesi Açısından Bir İnceleme, (Yayınlanmamış Yüksek Lisans Tezi), Eğitim Bilimleri Enstitüsü, Dokuz Eylül Üniversitesi, İzmir.

KANDİL İNGEÇ, Şebnem, TEKFIDAN Kamile ve Emine KARAGÖZ (2016). "Fizik Ders Kitaplarının Bilim Tarihi Açısından İncelenmesi", Fen Eğitimi ve Araştırmaları Derneği Fen Bilimleri Öğretimi Dergisi, 4(2): 168-187.

KANDİL İNGEÇ, Şebnem, TEKFIDAN, Kamile, KARAGÖZ, Emine ve Fatma KESKINN (2016). Ortaöğretim Fizik Dersi Öğretim Programının Bilim Tarihi Açısından İncelenmesi. International Management Research Congress (InMaR Congress), Poster sunum.

KAPUCU, Serkan ve Mehmet ÇILGIN (2016). "Lise Öğrencilerinin Ünlü Fizik Bilim İnsanları Hakkındaki Bilgilerinin Belirlenmesi”, Ahi Evran Üniversitesi Kırşehir Eğitim Fakültesi Dergisi (KEFAD) 17(2): 329-349.

KARASAR, Niyazi (2007). Bilimsel Araştrma Yöntemi, 17. Baskı, Ankara: Nobel Yayınları. 
KAYA, Aylin (2007). Fen Eğitiminde Bilim Tarihi Destekli Öğretimin Fen Bilgisi Öğretmen Adaylarının Bilim Doğasına İlişkin Görüşlerine Etkisinin Değerlendirilmesi, (Yayınlanmamış Yüksek Lisans Tezi), Fen Bilimleri Enstitüsü, Balıkesir Üniversitesi, Balıkesir.

KAYA, Özgül (2013). Yeni Fizik Dersi Öğretim Programının İlk Yıllardaki Uygulamalarına Yönelik Deneyimlerin İncelenmesi, (Yayınlanmamış Doktora Tezi), Eğitim Bilimleri Enstitüsü, Karadeniz Teknik Üniversitesi, Trabzon.

KAYA, Volkan Hasan, AFACAN, Özlem, POLAT, Dilber ve Ahmet URTEKİN (2013). "İlköğretim Öğrencilerinin Bilim İnsanı ve Bilimsel Bilgi Hakkındaki Görüşleri (Kırşehir İli Örneği)", Ahi Evran Üniversitesi Kırşehir Ĕgitim Fakültesi Dergisi (KEFAD), 14(1): 305-325.

KILIÇ, Fatma (2010). Ortaöğretim Kimya Ders Kitaplarında Atom Teorilerinin Sunumunun Bilim Tarihi ve Felsefesi Açısından İncelenmesi ve Öğretmen Görüşleri, (Yayınlanmamış Yüksek Lisans Tezi), Eğitim Bilimleri Enstitüsü, Gazi Üniversitesi, Ankara.

KOÇYİĞİT, Atilla ve Murat PEKTAŞ (2017). "Ortaokul Fen Bilimleri Ders Kitaplarındaki Okuma Parçalarının Bilim Tarihi Kullanımı Açısından İncelenmesi”, Cumhuriyet International Journal of Education-CIJE, 6(1): 185-199.

LAÇİN ŞİMŞEK, Canan (2009). "Fen Ve Teknoloji Dersi Öğretim Programları ve Ders Kitapları Bilim Tarihinden Ne Kadar ve Nasıl Yararlanıyor?”, Ilkögretim Online, 8(1): 129-145.

LAÇi̇N ŞİMŞEK, Canan (2011a) "Fen ve Teknoloji Dersi Öğretim Programı ve Kitaplarında Türk-İslam Bilginlerine Yer Verilme Durumu”, Türk Fen Eğitimi Dergisi, 8(4): 154-168.

LAÇİN ŞİMŞEK, Canan (2011b). "Bilimin Doğası ve Bilim Tarihi Dersinde Yapılan Çalışmaların Öğrencilerinin Bilim Tarihi İle İlgili Bilgi Düzeylerine Etkisi”, Necatibey Ĕgitim Fakültesi Elektronik Fen ve Matematik Eğitimi Dergisi, 5(1): 116138.

LAÇİN ŞIMMŞEK, Canan (2011c) "Science and technology teachers' situation of integrating history of science into their lessons", International Online Journal of Educational Sciences, 3(2): 707-742.

LAÇİN ŞİMŞEK, Canan ve Ahmet ŞİMŞEK (2010). "Türkiye'de Bilim Tarihi Öğretimi ve Sosyal Bilgiler Öğretmen Adaylarının Yeterlilikleri”, Uluslararası İnsan Bilimleri Dergisi [online], 7(2): 169-198.

METZ, Don, KLASSEN, Stephen, MCMILLAN, Barbara, CLOUGH, Micheal, and Joanne OLSON (2007). "Building A Foundation For Use of Historical Narratives". Science \& Education, 16: 313-334.

Millî Eğitim Bakanlığı (MEB) Talim ve Terbiye Kurulu Başkanlığı (2013). Ortaöğretim Fizik Dersi Öğretim Programı. 
MORGİL, İnci (1990). "Ülkemizde Fen Eğitimi, Sorunlar ve Öneriler", Hacettepe Üniversitesi Ĕ̈itim Fakültesi Dergisi, 5: 21-27.

ÖZDEMIR, Murat (2010). "Nitel Veri Analizi: Sosyal Bilimlerde Yöntembilim Sorunsalı Üzerine Bir Çalışma”, Eskişehir Osmangazi Üniversitesi Sosyal Bilimler Dergisi, 11(1): 323-343.

REID Struan and Patricia FARA (2010). The Usborne Book of Scientists, trans. by R Levent Aysever Arkhimedes'ten Einstein'a Bilim Adamları, 25. Bask1, Ankara: Tübitak Popüler Bilim Kitapları Yayınları.

SUSAM, Kevser Yeşim (2007). Hibritleşme Konusunun Tarihi Ve Felsefi Boyutunun Kimya Ders Kitaplarında Sunumu ve Öğretmen Görüşleri. (Yayınlanmamış Yüksek Lisans Tezi), Eğitim Bilimleri Enstitüsü, Gazi Üniversitesi, Ankara.

TAMIR, Pinchas (1989) "History And Philosophy of Science And Biological Education İn Israel”, Interchange, 20(2): 95-98.

TOPDEMIR, Hüseyin Gazi ve Yavuz UNAT (2008). Bilim Tarihi. Ankara: Pegem Akademi Yayıncilı.

TURAL, Güner (2012). "Gains of Physics Teacher Candidates in History of Science Course Conducted by Research and Discussion Approaches", The Journal of Instructional Technologies \& Teacher Education, 1(1): 52-67.

YILDIZ, Serap (2013). Lise Biyoloji Ders Kitaplarında Bilim Tarihi Kullanımının İncelenmesi, (Yayınlanmamış Yüksek Lisans Tezi), Eğitim Bilimleri Enstitüsü, Marmara Üniversitesi, İstanbul. 